\title{
The Social Dimension of the Entrepreneurial Motivation in the Central and Eastern European Countries
}

\author{
Zoltán Bartha, Andrea S. Gubik, Adam Bereczk
}

\begin{abstract}
A B S T R A C T
Objective: Discovering and categorising the entrepreneurial motivations of university student entrepreneurs in the CEE region, and uncovering the influencing factors behind the different motivation factors. The aim is to understand what factors shape the social motivations of entrepreneurs, and give insights on how these motivations may be enhanced in order to make social entrepreneurship more effective.

Research Design \& Methods: The study is based on the 2016 GUESSS database that contains 19.338 answers for eight selected CEE countries. Factor analysis was used to detect the motivation factors; a General Linear Model was set up to identify the influencing factors of the Social mission, one of the motivation factors of the university student entrepreneurs.

Findings: Five factors of entrepreneurial motivations were identified: Social mission, Customer focus, Competition/market focus, Individual goals, and Collective/community goals. Most of the factors are intrinsic in nature. Social mission factor is influenced by education, the entrepreneurship-related courses and programmes, a cultural dimension called uncertainty avoidance, and country-level characteristics that are not cultural in nature.

Implications \& Recommendations: Entrepreneurship courses and programmes influence attitudes and motivations, and so higher education institutions should focus on such programmes. The standard courses do not enhance the importance of intrinsic motivations, such as the social mission, so more emphasis should be put on the social dimensions.

Contribution \& Value Added: Our study contributes to the entrepreneurial motivations and social innovation literature, and calls for further comparative research, as the social mission GLM showed that country-level differences exist in the CEE region.

\section{Article type: research article \\ Keywords: entrepreneurial motivation; entrepreneurship; social innovation JEL codes: L26, L31, O35, O52}

Received: 5 October $2018 \quad$ Revised: 12 November 2018 Accepted: 12 November 2018
\end{abstract}

\section{Suggested citation:}

Bartha, Z., Gubik, A.S., \& Bereczk, A. (2019). The Social Dimension of the Entrepreneurial Motivation in the Central and Eastern European Countries. Entrepreneurial Business and Economics Review, 7(1), 9-27. https://doi.org/10.15678/EBER.2019.070101 


\section{INTRODUCTION}

The symbiosis of economic efficiency and social justice has formed the core of the European Union strategies. The Lisbon Agenda formulated in 2000 envisioned a 'dynamic and competitive [..] economy, [..] with greater social cohesion, and respect for the environment' (EMPL, 2010, p. 11). The current 'Europe 2020' strategy calls for 'smart, sustainable and inclusive growth', and efficiency goals (e.g. employment, R\&D) as well as fairness goals (e.g. education, poverty) are featured among its key indicators (EC, 2010, p. 3; Stanickova, 2017).

Entrepreneurship has traditionally been linked to economic efficiency, the first component of the dual core. Efficiency is improved by market competition, which on the other hand is driven by entrepreneurs bringing new ideas to the market. Better and more efficient ideas prevail, creating better and more jobs. Empirical statistics seem to confirm the above. The US government's Business Dynamics Statistics (BDS) dataset shows that startups (zero age firms) add an average of three million jobs per year, while the net employment effect of existing (age one or older) firms is typically negative (Kane, 2010).

Unfortunately, not all entrepreneurs have the textbook attitude. Hurst and Pugsley (2011) using data of entrepreneurs who were just about to start their businesses, show that few entrepreneurs have the desire to innovate or to grow, and most of them do not intend to bring new ideas to the market. Running tests on the BDS dataset, Haltiwanger, Jarmin and Miranda (2010) show that when controlling for firm age, there is no significant difference in job creation among firms of different sizes. Another way of putting this is that a high growth rate can come from firms of any size. Schrör (2006) using Eurostat data points out that younger entrepreneurs (below the age of 30) make businesses grow much faster than older ones (40 or above). Autio (2005) on the other hand highlights that enterprises run by highly qualified entrepreneurs grow faster.

Entrepreneurs may play a key role in the promotion of social justice as well. Current societal trends addressed by the Europe 2020 strategy can be perceived as opportunities for innovation. The process of new idea generation and implementation that tackles such societal challenges is called social innovation, which is innovation in the Oslo Manual sense with a social motive: its primary goal is to create social change (EC, 2013, p. 7). Entrepreneurs motivated by social goals are important agents in the initiation and implementation of social innovation.

Given the key importance of high growth firms (in improving efficiency), and social innovation (in promoting social justice), and taking into consideration the observations of Schrör (2006) and Autio (2005), in this study we concentrate on the entrepreneurial motivations of university student entrepreneurs. As Autio (2005) pointed out, firms ran by highly qualified entrepreneurs grow faster, which can be used as an argument for focusing on university students. But this is also a limitation of our study, since it does not cover all types of entrepreneurial youth. Motivations are important because they determine whether entrepreneurs seek to bring new ideas to the market, or they are satisfied with providing an existing service to an existing market. Motivations can have an effect on the social motives of enterprises as well.

Data from the Global University Entrepreneurial Spirit Students' Survey (GUESSS) database is used to identify the significant patterns of entrepreneurial motivations. Although GUESSS includes data for more than 50 countries, our study focuses on the Central and 
Eastern European (CEE) countries. The CEE members of the EU are not completely homogenous, but they have a similar historical background. They are also below the EU average in most economic and social progress indicators, including the Europe 2020 ones (Radulescu, Fedajev, Sinisi, Popescu, \& lacob, 2018). This means that meeting the Europe 2020 targets is a major challenge in the CEE region, which explains the focus of this study.

The aim of this study is to discover the important factors of entrepreneurial motivation, especially the ones connected to the social mission, and give insights on how these motivations could be enhanced. For this reason we identify the distinctive patterns of the entrepreneurial motivations of university student entrepreneurs in the CEE countries using factor analysis. We point out the main differences among CEE countries, and identify the factors that explain the differences. These factors are important to policy makers, since the economic efficiency and social justice goals may be achieved more easily by influencing them. We set up a General Linear Model of the Social mission of student entrepreneurs to point out the most important influencing factors.

\section{LITERATURE REVIEW}

\section{Main Definitions}

The theoretical background of our study is focused on three key definitions: entrepreneurship, entrepreneurial motivation, and social innovation.

Entrepreneurship can be defined as the mindset and process to create and develop economic activity by blending risk-taking, creativity and/or innovation with sound management, within a new or an existing organisation' (EC, 2003, p. 5).

Although motivation, motives, incentives, goals, etc. are a focal point of entrepreneurship research (see Zygmunt, 2018 and Carsrud, Brannback, Elfving, and Brandt (2017) for a comprehensive review of the literature), there is no clear definition of entrepreneurial motivation. Here we build on the ideas of Maslow (1946), and Nuttin (1984), and define entrepreneurial motivation as a human drive to satisfy certain needs (including, in its highest form, achievement motivation), and an aspect of the entrepreneur's behaviour that is responsible for moving behaviour toward a certain direction or object.

Social innovation is basically an innovation process with a strong social motive. The World Economic Forum defines it as 'the application of innovative, practical, sustainable, business-like approaches that achieve positive social and/or environmental change, with an emphasis on low-income or underserved populations' (WEF, 2013, p. 3).

\section{Entrepreneurial Motivations}

The motivation of entrepreneurs is typically linked to entrepreneurship through entrepreneurial intentions. The way enterprises react to challenges, identify business opportunities, and develop plans to take advantage of them is an intentional behaviour that is strongly influenced by entrepreneurial intentions (Bird, 1988). The dominant model of entrepreneurial intentions is based on the theory of planned behaviour (Ajzen, 1991), and the idea of the entrepreneurial event (Shapero, 1982), and was developed by Krueger and his associates. This linear model of entrepreneurial intentions suggests that intentions are influenced by perceived feasibility (self-efficacy, the confidence of the individual in suc- 
cessfully addressing the entrepreneurial challenges), and by perceived desirability (the desire of the individual to start tasks related to entrepreneurship) (Krueger, Reilly, \& Carsrud, 2000). Motivations in this model are drivers of the latter, perceived desirability (e.g. Douglas, 2013; Nicolli, Ramaciotti, \& Rizzo, 2016).

Elfving, Brännback and Carsrud (2009) argue that the intention process may not be linear, and they suggest a new model called context-specific entrepreneurial intentions model (Elfving et al., 2009, p. 29). Motivations are explicitly included in the Elfving et al. (2009) model, and in fact they are the first factor to be considered once a triggering event occurs.

Existing motivational theories are mostly rooted in economics and psychology, and they often conflict with each other. Drive theories concentrate on the so called push factors; the incentives approach focuses on the pull factors. Entrepreneurs are motivated by both achieving a certain success, and avoiding failure (Deci, 1975). Motivation can come internally (intrinsic motivation), and externally (extrinsic motivation). Intrinsic motivation comprises of intangible motives that endogenously foster an entrepreneur to make a move. The need for achievement, self-actualisation or reciprocity are all examples of such intrinsic motivations (Nuttin, 1984). Extrinsic motivation on the other hand refers to external rewards (e.g. recognition, monetary payoff).

Empirical tests confirm the idea that motivations influence behaviour, and so they are an important influencer of entrepreneurial intentions and activity. Ryan and Deci (2000) find that if the competence, relatedness and autonomy needs of the individual are satisfied, intrinsic motivation is the primary influencer. If, however, the above needs are not met, extrinsic motivators become dominant in behaviour. Although not an empirical, but rather a theoretical investigation, Benabou and Tirole (2003) show in their analysis how intrinsic and extrinsic motivations effect the individual's behaviour in different circumstances.

Lüthje and Franke (2003) tested MIT engineering students, and they found that personality traits that can be interpreted as motivation factors have a strong impact on the entrepreneurial intentions. Surveying engineering students in Spain, Barba-Sanchez and Atienza-Sahuquillo (2017) also find that the motivation, namely the need for independence is in a significant association with entrepreneurial intentions. Focusing on academics at the University of Ferrara, Antonioli, Nicolli, Ramaciotti and Rizzo (2016) find that academic entrepreneurial intentions are mostly driven by intrinsic motivations, while the role of extrinsic motivations are largely mediated by the academic position and the work environment. Chmielecki and Sułkowski (2016) asking Polish undergraduate business students found that students associate both intrinsic (e.g. journey, adventure) and extrinsic (e.g. exploitation) metaphors with entrepreneurship. These social and economic effects also embrace the possibility of strengthening the foundations of a modern economic governance structure supported by the new generations of higher education entrepreneurs (O'Leary, 2015). On the other hand, the social and economic importance of promoting entrepreneurial intentions between university students is wildly accepted amongst scholars, and the influence of entrepreneurship education in this process cannot be underestimated (see the study of Krpálková, Krelová, and Krpálek, 2016; Badzińska and Brzozowska-Woś, 2017; Çera et al., 2018; Dvorský et al., 2019).

Motivations also influence behaviour through intentions. Doing basic association tests on a sample of Czech small and medium-sized enterprises (SMEs), Kozubikova, Sopkova, Krajcik and Tyll (2017) find that SMEs led by entrepreneurs with an extrinsic 
motivation (starting a business for money) are more likely to develop new products (i.e. engage in innovation). Running multivariate tests on a large sample of French start-ups, Gundolf, Gast and Geraudel (2017) show that the entrepreneurial motivation is associated with the innovation method the firms choose. Wach and Wojciechowski (2016) tested Cracow-based students, and found that the risk attitude, and the business/nonbusiness study field also effect entrepreneurial intentions.

Sieger, Gruber, Fauchart and Zellweger (2016) investigate the social identity of entrepreneurs. They also use the GUESSS database, and concentrate on the same entrepreneurial motivation questions. Following some adjustments (deleting some questions from the analysis), they establish three factors, that they identify as Darwinian, Communitarian, and Missionary identities. They find that there are significant regional differences in entrepreneurial identities among Western regions.

\section{Social Innovation and Business Enterprises}

Social innovation is the main process through which entrepreneurs driven by different motivations can contribute to social justice. European countries face a number of global, European and country-specific problems that go beyond the issue of economic efficiency. Climate change, demographic trends, growing unemployment and social isolation among the disadvantaged, rapid changes in health care and in the natural environment, negative externalities of global competition, mass digital illiteracy are examples of global challenges. Challenges that the European Union wants to address include: aging population; early school dropouts; sex discrimination; quality and efficiency of health care and public services. The peripheries of the EU, especially the Mediterranean and the Central and Eastern European members face further challenges related to budgetary limitations and social tensions.

European countries, and especially the peripheral regions are in great need of organisations and initiatives that not only help in achieving stable growth, but they also contribute to the reduction of social inequity. Initiatives that are based on social interaction and address social problems on the level of communities are commonly referred to as social innovation. According to the European Commission, 'the social innovation approach is understood to mean not only a new governance mode working across traditional fields of responsibilities with an active involvement of citizens, which is effective in addressing the challenges of climate mitigation, social justice, ageing, etc., but also the culture of trust and risk-taking which is needed to promote scientific and technological innovations' (EC, 2011, p. 7). Some macro-level institutional models, such as the one developed by Turker and Vudal (2017, Figure 1 on p. 101), explain how the social innovation process is connected to the rest of the economy.

Enterprises that were established with a social innovation goal in mind are called social enterprises. Some studies exclude traditional profit-oriented firms from their analysis, like Fici (2015) and Soviana (2015), and also some well-known experts (e.g. the Yale School of Management, The Goldman Sachs Foundation Partnership on Nonprofit Ventures, or the Seattle Social Enterprise Consultants) do so (Kerlin, 2006), while others suggest that profit firms can also be included if their vision and the attitude of the entrepreneur makes them sensitive to social issues (UnLtd, 2014; Lönnström, 2015; Fekete et al., 2017; Bilan et al., 2017). Mugler (1993) when assessing the social and economic utility of SMEs, lists the following 12 components: economic result; stabilising a pluralist society; strengthening the system of market economy; extending supply in the market; promoting technological 
development; sharing risk - crisis prevention; performance - motivation; improving quality of life; supporting vocational training; stabilising growth; environmental protection; foreign trade. These factors harmonise with the dual core of efficiency and justice.

\section{MATERIAL AND METHODS}

GUESSS investigates entrepreneurial intentions and activities of university students. The survey explores the students' career intentions, investigates their motivations and goals, their orientation and behaviour in their business activity. It also analyses the role of higher education and culture in the decision. We investigate the sample of CEE countries. Table 1 shows the distribution of the sample according to the countries of the respondents.

Table 1. Distribution of Answers in the CEE Sample

\begin{tabular}{|l|r|r|}
\hline \multicolumn{1}{|c|}{ Country } & Frequency & Valid in \% \\
\hline Estonia (EST) & 811.000 & 4.2 \\
\hline Latvia (LVA) & 426.000 & 2.2 \\
\hline Poland (POL) & 6.388 & 33.0 \\
\hline Czech Republic CZE) & 1.135 & 5.9 \\
\hline Slovak Republic (SVK) & 3.266 & 16.9 \\
\hline Hungary (HUN) & 5.182 & 26.8 \\
\hline Slovenia (SVN) & 575.000 & 3.0 \\
\hline Croatia HRV) & 1.555 & 8.0 \\
\hline Total & 19.338 & 100.0 \\
\hline
\end{tabular}

Source: own elaboration.

The female-male ratio of the sample is $64.4-35.6 \%$. As for the field of study, $32.9 \%$ of the respondents studied economics and law, 23.2\% engineering (incl. computer sciences and architecture), 9.6\% human medicine/health sciences, $8.5 \%$ social sciences, $5.8 \%$ arts/humanities, $5.4 \%$ mathematics and natural sciences, and $1.1 \%$ science of art. The exact field of study cannot be identified in the case of $13.5 \%$ of the students. $73.3 \%$ of the respondents were 24 or younger at the time of the survey, $17.9 \%$ were $25-30$, and only $8.8 \%$ were older than 30 . The share of entrepreneurs within the sample is not homogenous (Table 2).

After reviewing the available literature and previous research findings, there are still some questions that remain unanswered. That is why the following hypotheses are formulated and tested:

H1: There are significant differences among CEEC countries in the social dimension of entrepreneurial motivations.

H2: Education has a significant impact on social motivations.

H3: Cultural differences affect the development of social motivations.

H4: Students who plan long-term entrepreneurial career are more committed to the social mission.

H5: Business orientation is a significant explanation of the differences observed in social motivations.

Mainly descriptive statistics were used to describe entrepreneurial motivations (especially the role of intrinsic motivations) in the CEE region, and the stochastic relationships 
among the variables were tested. The General Linear Model (GLM) was used to check the combined effect of the analysed variables. The analysis was conducted with SPSS 25.0. The structure of the tables follows the logic of the output tables of the software.

Table 2. The Share of Those Who Answered 'Yes' to the Question: Are You Already Running Your Own Business / Are You Already Self-employed?

\begin{tabular}{|l|c|c|c|c|c|c|}
\hline \multirow{2}{*}{ COUNTRY } & \multirow{2}{*}{$\begin{array}{c}\text { Ratio of en- } \\
\text { trepreneurs }\end{array}$} & \multicolumn{5}{|c|}{ Within this } \\
\cline { 3 - 7 } & & self employed & micro & small & medium & large \\
\hline EST & 12.7 & 30.2 & 68.8 & 0 & 0 & 1 \\
\hline LVA & 7.7 & 19.4 & 80.6 & 0 & 0 & 0 \\
\hline POL & 3.8 & 45.0 & 45.0 & 7.0 & 3.1 & 0 \\
\hline CZE & 10.1 & 53.4 & 42.7 & 2.9 & 1.0 & 0 \\
\hline SVK & 6.9 & 58.3 & 39.4 & 2.3 & 0 & 0 \\
\hline HUN & 5.6 & 48.4 & 47.7 & 3.9 & 0 & 0 \\
\hline SVN & 6.8 & 25.0 & 66.7 & 5.6 & 2.8 & 0 \\
\hline HRV & 3.3 & 19.1 & 68.1 & 8.5 & 4.3 & 0 \\
\hline
\end{tabular}

Source: own elaboration.

\section{RESULTS}

The motivation and goals were surveyed by Question 9.2 of GUESSS. The first batch of questions discovered the motivations that were most important when starting the business (Table 3).

Table 3. Business Start-up Motivations

\begin{tabular}{|l|c|c|c|c|c|c|c|c|}
\hline \multicolumn{1}{|c|}{ Action } & EST & LVA & POL & CZE & SVK & HUN & SVN & HRV \\
\hline to make money and become rich. (1/1) & 4.24 & 5.45 & 5.14 & 4.47 & 4.76 & 4.83 & 3.89 & 4.31 \\
\hline to mainly achieve financial success. (1/2) & 4.35 & 5.62 & 5.37 & 4.79 & 4.96 & 4.63 & 4.97 & 5.06 \\
\hline to advance my career in the business world. (1/3) & 4.51 & 4.90 & 5.29 & 4.50 & 4.93 & 4.77 & 4.83 & 5.56 \\
\hline to be able to signal my capabilities to others. (1/4) & 4.59 & 5.40 & 4.32 & 4.44 & 4.69 & 4.22 & 4.42 & 4.96 \\
\hline $\begin{array}{l}\text { to solve a specific problem for a group of people } \\
\text { that I strongly identify with. (1/5) }\end{array}$ & 4.43 & 4.97 & 3.91 & 3.55 & 4.14 & 4.41 & 4.29 & 4.60 \\
\hline $\begin{array}{l}\text { to play a proactive role in shaping the activities of a } \\
\text { group of people that I strongly identify with. (1/6) }\end{array}$ & 3.37 & 4.83 & 3.77 & 3.48 & 3.87 & 4.30 & 3.50 & 4.38 \\
\hline $\begin{array}{l}\text { to solve a societal problem that private businesses } \\
\text { usually fail to address. (1/7) }\end{array}$ & 3.28 & 4.17 & 3.84 & 2.85 & 3.39 & 3.50 & 3.39 & 4.15 \\
\hline $\begin{array}{l}\text { to do something that allows me to enact values } \\
\text { which are core to who I am. (1/8) }\end{array}$ & 5.47 & 5.65 & 4.59 & 4.89 & 5.07 & 4.94 & 5.17 & 5.43 \\
\hline $\begin{array}{l}\text { to play a proactive role in changing how the world } \\
\text { operates. (1/9) }\end{array}$ & 4.45 & 4.66 & 4.65 & 3.74 & 4.04 & 4.28 & 3.97 & 4.65 \\
\hline
\end{tabular}

Please indicate your level of agreement with the following statements. I created my firm in order...

(1=strongly disagree, $7=$ strongly agree)

Source: own elaboration.

The second batch of questions investigated the primary motives of the founders (Table 4). 
Table 4. Founder Motivations

\begin{tabular}{|l|l|l|l|l|l|l|l|l|}
\hline \multicolumn{1}{|c|}{ Action } & EST & LVA & POL & CZE & SVK & HUN & SVN & HRV \\
\hline $\begin{array}{l}\text { to operate my firm on the basis of solid manage- } \\
\text { ment practices. (2/1) }\end{array}$ & 4.33 & 4.94 & 5.71 & 4.45 & 5.44 & 4.91 & 4.75 & 5.29 \\
\hline $\begin{array}{l}\text { to have the financial prospects of my business } \\
\text { thoroughly analysed. (2/2) }\end{array}$ & 4.46 & 5.10 & 5.61 & 4.76 & 5.56 & 5.76 & 4.64 & 5.63 \\
\hline $\begin{array}{l}\text { to provide a product/service that is useful to a } \\
\text { group of people that I strongly identify with. (2/3) }\end{array}$ & 5.44 & 5.68 & 5.23 & 4.71 & 5.63 & 5.57 & 5.08 & 5.63 \\
\hline $\begin{array}{l}\text { to convey to my customers that I want to satisfy } \\
\text { their needs rather than just to do business. (2/4) }\end{array}$ & 5.70 & 5.93 & 5.42 & 5.34 & 6.05 & 5.87 & 5.75 & 5.82 \\
\hline $\begin{array}{l}\text { to be able to express to my customers that I funda- } \\
\text { mentally share their views, interests and values. (2/5) }\end{array}$ & 5.44 & 6.00 & 4.93 & 5.04 & 5.67 & 5.27 & 5.14 & 5.69 \\
\hline $\begin{array}{l}\text { to be true in serving a group of people that I } \\
\text { strongly identify with. (2/6) }\end{array}$ & 5.59 & 5.63 & 4.51 & 4.44 & 5.23 & 5.37 & 5.33 & 5.48 \\
\hline $\begin{array}{l}\text { to be a highly responsible citizen of our world. (2/7) } \\
\text { to make the world a 'better place'. (2/8) }\end{array}$ & 4.28 & 4.93 & 5.14 & 4.17 & 5.11 & 5.11 & 5.08 & 5.53 \\
\hline to
\end{tabular}

As a firm founder, it is very important to me... (1=strongly disagree, $7=$ strongly agree)

Source: own elaboration.

The third batch of questions (Table 5) concentrates on the most important goals during the operation of the firm.

Table 5. Motivations During Operation

\begin{tabular}{|l|l|l|l|l|l|l|l|l|}
\hline \multicolumn{1}{|c|}{ Action } & EST & LVA & POL & CZE & SVK & HUN & SVN & HRV \\
\hline $\begin{array}{l}\text { to have a strong focus on what my firm can achieve } \\
\text { vis-à-vis the competition. (3/1) }\end{array}$ & 5.41 & 5.57 & 5.50 & 4.93 & 5.31 & 5.34 & 5.00 & 5.43 \\
\hline $\begin{array}{l}\text { to establish a strong competitive advantage and sig- } \\
\text { nificantly outperform other firms in my domain. (3/2) }\end{array}$ & 5.32 & 5.63 & 5.50 & 4.87 & 5.53 & 5.04 & 5.03 & 5.42 \\
\hline $\begin{array}{l}\text { to have a strong focus on a group of people that I } \\
\text { strongly identify with. (3/3) }\end{array}$ & 4.94 & 5.11 & 4.69 & 4.40 & 5.07 & 5.29 & 5.11 & 5.02 \\
\hline $\begin{array}{l}\text { to support and advance a group of people that I } \\
\text { strongly identify with. (3/4) }\end{array}$ & 4.98 & 5.45 & 4.65 & 4.41 & 4.74 & 5.25 & 5.08 & 5.43 \\
\hline $\begin{array}{l}\text { to have a strong focus on what the firm is able to } \\
\text { achieve for society-at-large. (3/5) }\end{array}$ & 4.96 & 5.07 & 4.54 & 4.45 & 5.11 & 4.93 & 4.89 & 5.41 \\
\hline $\begin{array}{l}\text { to convince others that private firms are indeed able } \\
\text { to address the type of societal challenges that my } \\
\text { firm addresses. (3/6) }\end{array}$ & 3.93 & 4.58 & 4.66 & 4.08 & 4.69 & 4.65 & 4.47 & 5.35 \\
\hline
\end{tabular}

When managing my firm, it is very important to me... (1=strongly disagree, 7=strongly agree)

Source: own elaboration.

\section{Factors of Entrepreneurial Motivation}

There are significant differences among countries in case of all motives and goals (the value of Eta is between 0.15 and $0.3, p=0.000$ ). Further differences can be detected according to sex, age, evaluation of the higher education environment, and study field. The outcomes, however, are very difficult to map because of the high number of variables. In order to decrease the number of variables, and to get a better idea of the background structure, a factor analysis was conducted, and five factors were identified. The value of 
the Kaiser-Meyer-Olkin is 0.898 , which means that our data are perfectly suited for a factor analysis. The five factors explain $66.75 \%$ of the total variance. Table 6 shows the factor weights of all the variables belonging to our five factors.

Table 6. Factor Weights and Factors of Entrepreneurial Motivations

\begin{tabular}{|c|c|c|c|c|c|}
\hline \multirow{2}{*}{ Question } & \multicolumn{5}{|c|}{ Component } \\
\hline & 1 & 2 & 3 & 4 & 5 \\
\hline $1 / 9$ & 0.787 & & & & \\
\hline $2 / 8$ & 0.743 & & & & \\
\hline $1 / 7$ & 0.734 & & & & \\
\hline $3 / 6$ & 0.669 & & & & \\
\hline $3 / 5$ & 0.647 & & & & \\
\hline $2 / 7$ & 0.580 & & & & \\
\hline $1 / 8$ & 0.570 & & & & \\
\hline $2 / 5$ & & 0.780 & & & \\
\hline $2 / 4$ & & 0.770 & & & \\
\hline $2 / 3$ & & 0.742 & & & \\
\hline $2 / 6$ & & 0.722 & & & \\
\hline $3 / 1$ & & & 0.820 & & \\
\hline $3 / 2$ & & & 0.804 & & \\
\hline $2 / 1$ & & & 0.637 & & \\
\hline $2 / 2$ & & & 0.587 & & \\
\hline $1 / 2$ & & & & 0.853 & \\
\hline $1 / 1$ & & & & 0.817 & \\
\hline $1 / 3$ & & & & 0.619 & \\
\hline $1 / 4$ & & & & 0.428 & \\
\hline $3 / 3$ & & & & & 0.649 \\
\hline $1 / 6$ & & & & & 0.628 \\
\hline $3 / 4$ & & & & & 0.622 \\
\hline $1 / 5$ & & & & & 0.618 \\
\hline
\end{tabular}

Extraction Method: Principal Component Analysis; Rotation Method: Varimax with Kaiser Normalization; a. Rotation converged in 12 iterations

Source: own elaboration.

There are five distinctive motivations of university student entrepreneurs in the CEE countries. In the following section we provide a short description of the five factors.

1. Social mission: one of the motivators is to follow a strong societal agenda, play a proactive role in trying to change the society, solve social problems, and spread specific values in the community. The social mission is a purely intrinsic motivation (Component 1/Table 6).

2. Customer focus: another specific motivation is to identify and serve the special needs of the customers, which also means that the entrepreneurs with a strong customer focus motivation tend to focus on a specific group of customers instead of the wider public. The customer focus is an intrinsic motivation (Component 2/Table 6).

3. Competition/market focus: The third group of motivators prompt to an analytical focus (the goal is to have a very good understanding about the market position of the 
firm, about the strength and opportunities), and the strong will to compete and to outperform the competitors. Yet another intrinsic motivation (Component 3/Table 6).

4. Individual goals: Factor 4 is the only one in our analysis that includes extrinsic motivations (Component 4/Table 6).

5. Collective/community goals: Similarly to Factor 1 , this factor also includes variables that are focused on solving social challenges and playing a proactive role in the community. The difference between the two factors is the scope: while Factor 1 includes goals that concern the society as a whole, Factor 5 is limited to smaller, specific communities. In this sense, Factor 5 is the closest to the motivations of the social entrepreneurs (Component 5/Table 6).

\section{Differences in the Five Motivation Factors}

When trying to uncover the possible explanations of the differences in the five motivation factors, the following six areas were tested:

\section{Student Demography (sex, age)}

Significant differences between the sexes can only be detected in the case of 2. Customer focus and 4. Individual goals. The females in the sample have a stronger customer focus, while the extrinsic motivations of Factor 4 are stronger in the case of the male respondents. As far as age is concerned, Factor 4 is the only motivator where a significant difference is observable. The relationship between age and the Individual goals is weak, and has a negative sign $(r=-0.16, p=0.000)$, which means that the extrinsic motivations are slightly stronger among the younger students.

\section{CEE Country Differences}

The motivation factors significantly differ among the CEE countries (the value of Eta is between 0.13 and $0.2, p=0.000$ ). Figure 1 shows the differences in Factor 1 and Factor 5.

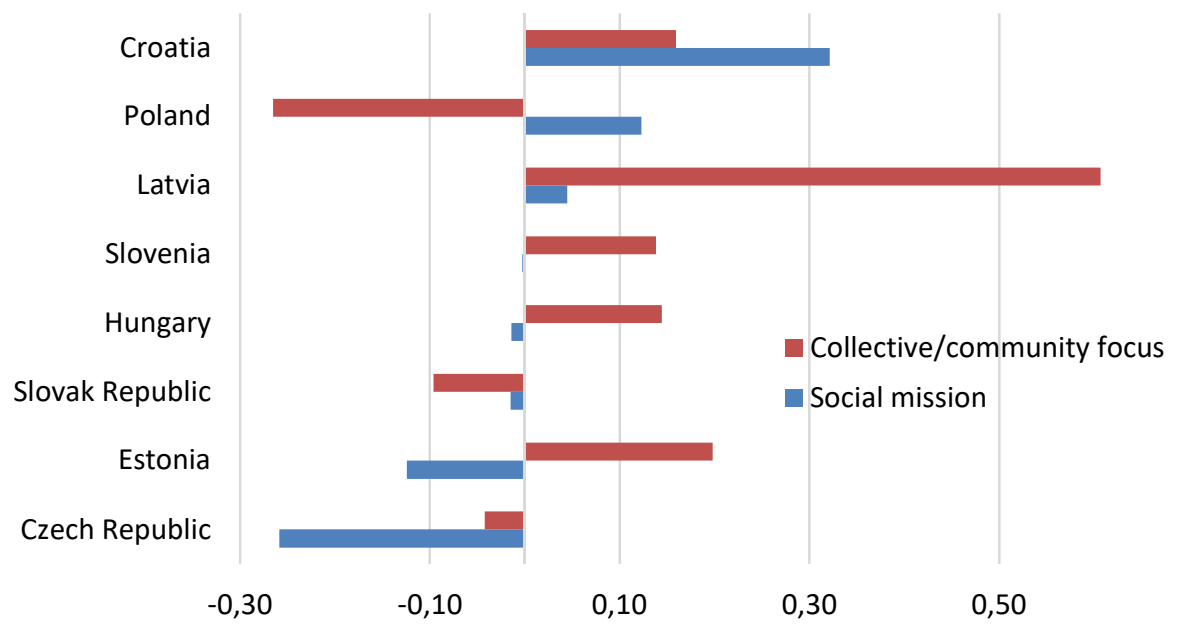

Figure 1. Differences among the CEE countries in the Social mission and the Collective/community goals motivations of the entrepreneurs

Source: own elaboration. 
In terms of Social mission, Croatia has the highest factor score, and Poland and Latvia are also above the average. The Czech Republic is on the other end of the spectrum, which means that the societal agenda in the motivation of the Czech entrepreneurs is significantly weaker than in other CEE countries. Estonia also scores below the average, while three countries: Slovenia, Hungary and Slovakia have factor values very close to the average.

The Community focus of student entrepreneurs is highest in Latvia, and is above the CEE average in Estonia, Slovenia and Hungary. Poland, Slovakia, and the Czech Republic are below the average in this respect.

\section{Higher Education Specifics}

In our study we investigated the effect of three variables related to higher education: the study field of the student; the presence of entrepreneurship related courses; and the entrepreneurial atmosphere of the university.

Our respondents are significantly different in motivation Factor 3 (Competition/market focus), and Factor 4 (Individual goals), if we involve the study field in the analysis. Law and economics/business students score above the average in both factors, while students of health sciences, arts and humanities and science of art have below the average factor values.

Courses (compulsory or elective ones) and programmes with an entrepreneurial focus are in a positive and significant association with Factor 3 (Competition/market focus), and Factor 4 (Individual goals). These results may indicate that the education can influence the analytical and materialistic motivations of the students, but it does not have an effect on the more intrinsic, societal motivations.

The way students perceive the entrepreneurial atmosphere surrounding the university is positively associated with Factor 1 (Social mission), Factor 3 (Competition/market focus), and Factor 5 (Collective/community goals). While formal courses seem to affect the materialistic motivations, the entrepreneurial environment of the university may influence the societal motivations of the student entrepreneurs.

\section{Cultural Differences}

Our database consisted of information on 4 GLOBE dimensions (for a detailed description see House et al., 2004), namely In-Group Collectivism (IGC), Uncertainty Avoidance (UA), Performance Orientation (PO), and Power Distance (PD). IGC is in a weak but significant association with Factor 2 (Customer focus; $r=0.106, p=0.001$ ), and Factor 3 (Competition/market focus; $r=0.151, p=0.000$ ). UA is in weak association with three of the motivation factors: Factor 1 (Social mission; $r=0.117, p=0.000)$, Factor $2(r=0.108$, $\mathrm{p}=0.001)$, and Factor $3(r=0.174, p=0.000)$. Finally, there is a weak but significant association between PO and Factor 3 as well $(r=0.114, p=0.000)$. The relationships are very week, but one of the possible interpretations of the results is that a stronger market/competition focus (e.g. to establish a strong competitive advantage over other firms, focus on innovation - see the results presented in point 6) in the motivation is associated with more collectivist (e.g. duties are important in the behaviour), high uncertainty avoidance (e.g. taking calculated risks, relying on formalised procedures), and high performance oriented (e.g. valuing competition and materialistic incentives) student entrepreneurs. Entrepreneurs with high uncertainty avoidance can have a stronger social mission focus in their motivations as well. 


\section{Career Plans}

$51.7 \%$ of those students who ran a business at the time of the survey plan to make the enterprise their primary source of income after graduation. $32.7 \%$ of the rest wish to work for an SME or a large corporation, and the final $23.9 \%$ target the government, the academic or the non-profit sector for a job. Students who would like to continue their careers as an entrepreneur (either by taking over an already existing enterprise, or by funding a new one), are generally more motivated in all factors, but especially in the case of Factor 1 (Social mission), and Factor 4 (Individual goals).

Among those who envisioned their career as an employee immediately after graduation, the Social focus was higher for those targeting the non-profit sector, and Factor 5 (Collective/community focus) was higher for those targeting employment at small enterprises. This second group can be characterised with a lower Factor 4 (Individual goals) score.

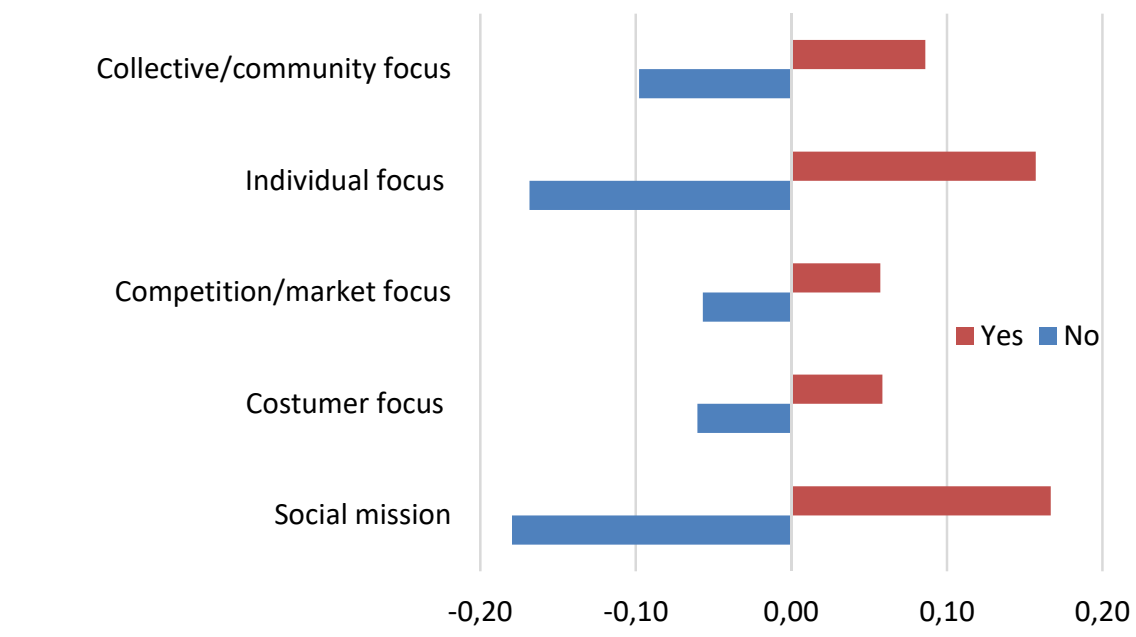

Figure 2. Factor values according to career choice intentions

(Do you want this business to become your main occupation after graduation? (yes/no)) Source: own elaboration.

\section{Business Orientation}

We also tested the association between ideas about the innovativeness of the enterprises and the entrepreneurial motivation factors. The GUESSS questionnaire asked student entrepreneurs about the importance of the following goals: to introduce a new generation of products/services; to extend the product/service range; to open up new markets; to enter new technology fields; to improve existing product/service quality; to improve flexibility in producing goods/services; to improve yield or reduce material consumption. We found that students more committed to innovation have higher factor values with the exception of Factor 5 (Collective/community focus). The difference is even more robust if commitment to exploration innovation (seeking new knowledge/technology) is compared to other innovation goals. Factor analysis was used to separate exploration innovation goals from exploitation ones. The strongest association was detected with Factor 3 (Competition/market focus; $r=0.366, p=0.000$ ). 
Another question related to the entrepreneurial orientation (EO) measured risk taking, innovativeness and proactivity of students (based on Covin-Slevin, 1989). All three areas of EO are in a weak but significant association with Factor 1 (Social focus; $r=0.207,0.206$ and $0.204, p=0.000$ ), and in an even weaker one with Factor 5 (Collective/community focus). Risk taking is in significant association with Factor 4 (Individual goals). The linear correlation coefficient of the other relationships is around 0.1 (but significant). These results suggest that the traditional EO concept can be used to social enterprises as well, as it was shown in earlier studies (Balta, Darlington, Smith, \& Cornelius, 2012; Kusa, 2016; Kozubíková et al., 2017).

\section{A Regression Model of Social Mission}

The variables tested in our study are generally in a weak but significant association with the motivation factors. To set up a regression model, we need to use a method that shows both the partial and the combined effect of these variables. For this reason we set up a GLM in our study. GLM integrates linear regression and variance analysis, and it enables to express the dependent variable as a function of both continuous, and discrete independent variables (Ketskemety \& Izso, 2005). Our specific model is a univariate GLM. Its dependent variable is Factor 1 (Social mission), which is especially important for social innovation, and all the previously introduced variables were used as independent variables.

We have to reject our null hypothesis stating that the sample is homogeneous according to Factor 1 , because of the low value of $p(0.000)$. The explanatory power is only $14 \%$, shown by the adjusted $r$ square at the end of Table 7.

Table 7. Social Mission GLM Test Results

\begin{tabular}{|l|c|r|r|r|c|}
\hline \multicolumn{7}{|c|}{ Dependent Variable: Social mission } \\
\hline \multicolumn{1}{|c|}{ Source } & Type III Sum of Squares & df & Mean Square & \multicolumn{1}{c|}{ F } & \multicolumn{1}{c|}{ Sig. } \\
\hline Corrected Model & $149.774^{\text {a }}$ & 20 & 7.489 & 8.627 & 0.000 \\
\hline Intercept & 5.955 & 1 & 5.955 & 6.860 & 0.009 \\
\hline Proactivity & 10.777 & 1 & 10.777 & 12.415 & 0.000 \\
\hline Studies & 11.396 & 1 & 11.396 & 13.128 & 0.000 \\
\hline Risk-taking & 5.134 & 1 & 5.134 & 5.915 & 0.015 \\
\hline Uncertainty avoidance & 4.744 & 1 & 4.744 & 5.465 & 0.020 \\
\hline Exploration & 11.774 & 1 & 11.774 & 13.564 & 0.000 \\
\hline Career choice & 12.502 & 1 & 12.502 & 14.403 & 0.000 \\
\hline Country & 13.798 & 7 & 1.971 & 2.271 & 0.027 \\
\hline Career choice * Country & 18.160 & 7 & 2.594 & 2.989 & 0.004 \\
\hline Error & 798.604 & 920 & 0.868 & & \\
\hline Total & 948.483 & 941 & & & \\
\hline Corrected Total & 948.378 & 940 & & & \\
\hline
\end{tabular}

${ }^{\text {a }}$ R Squared $=0.158$ (Adjusted R Squared $=0.140$ )

Source: own elaboration.

The variables that have a significant partial effect (even when all the other variables are controlled for) are worth discussing despite the low explanatory power of the model. The area of study does not affect the Social motivation goal, but education does. The variable for the presence of entrepreneurial courses/programmes was used in the model, but the 
university atmosphere is also a significant influencing factor (this latter one was left out of our model because of the multicollinearity between the two education variables).

Our variables measuring EO tell us that risk taking, commitment to innovation, and proactive approach are all important in developing a Social mission motivation in the entrepreneurs. Those students who wish to continue as an entrepreneur after graduation are also more committed to the Social mission. As far as cultural determinants are concerned, Uncertainty avoidance is the only remaining significant factor. The need of the student to rely on formal procedures, to be orderly, and to only take calculated risk seems to coincide with a stronger commitment to the Social mission of an enterprise. Significant differences can also be detected among countries (even when UA is controlled for). The demographic characteristics of the students (sex, age), and firm specific characteristics (size, profitability) do not influence the Social mission factor of motivation.

\section{CONCLUSIONS}

Since 2003, GUESSS research has grown to an international scale. The conceptualisation and operationalisation of research issues have matured, which guarantees that a reliable database is available for the countries surveyed. With the established measures the reliability of research teams is also assured. The GLM model of Social mission is statistically acceptable, although its explanatory power is only $14 \%$. The low explanatory power is one of the key limitations of our findings, the other being the fact that we limited our analyses to the motivations of university student entrepreneurs.

An analogy can be drawn between the identified five factors of entrepreneurial motivation, and Sieger and his colleagues' three factors of entrepreneurial social identity. (Sieger et al., 2016) Their factor called Darwinian identity corresponds to our Factor 3 (Competition/market focus), the one called Missionary identity corresponds to Factor 5 (Collective/community goals), and the Missionary identity corresponds to Factor 1 (Social mission). They find that considerable regional differences exist within the Western world as far as the factors are concerned; our findings indicate that the differences can be observed on a country-level as well.

Our results suggest that entrepreneurship courses/programmes can prove beneficial in boosting the social mission of entrepreneurs. These initiatives provide students with knowledge necessary to start and to manage a business, and with modern teaching methods they can also get hands on experience about the practical challenges of an enterprise. Furthermore, the knowledge, the experience, the examples of good practice, and entrepreneurship tutoring increase the self-confidence of students, which on the other hand makes them more convinced that they are able to cope with the role and duties of an entrepreneur. These developments, on the other hand, form the attitudes of students as well. One of the roles of entrepreneurial programmes is to create a positive attitude toward starting a business, but making the orientation of the students more entrepreneurial (risk taking, innovative, and proactive) is an equally important goal.

An area where we feel education is lacking, is the lack of attention of these courses to the social goals of an enterprise. Some courses explain the societal challenges of our societies, and the idea, the targets, and the characteristics of social enterprises are also presented in some (mostly business-oriented) programmes. But the issue of social enterprises is still isolated from the mainstream of entrepreneurial studies in the CEE region. 
Another important result is that there are considerable country-related differences in the Social mission of university student entrepreneurs. These differences emerge even when uncertainty avoidance is controlled for, meaning that they are of non-cultural origin (or are determined by cultural factors that were not part of our analysis). This finding calls for further comparative analysis in the CEE region to identify good institutional practices. The need for further research is also apparent from the low explanatory power of the GLM of Social mission set up in our study.

\section{REFERENCES}

Ajzen, I. (1991). The theory of planned behavior. Organizational Behavior and Human Decision Processes, 50(2), 179-211. https://doi.org/10.1016/0749-5978(91)90029-s

Antonioli, D., Nicolli, F., Ramaciotti, L., \& Rizzo, U. (2013). The effect of intrinsic and extrinsic motivations on academics' entrepreneurial intention. Administrative Science, 6(4), 15. https://doi.org/10.3390/admsci6040015

Autio, E. (2005). Report on high-expectation entrepreneurship. London, UK: London Business SchoolBabson College.

Badzińska, E., \& Brzozowska-Woś, M. (2017). Entrepreneurship in Virtual Economy: the Case of Currency One SA. Journal of Management and Business Administration, 25(3), 2-19.

Balta, M.E., Darlington, C., Smith S.L., \& Cornelius, N. (2012). Entrepreneurial orientation and social innovation practices in social enterprises: The rhetoric and reality. International Journal of Business and Social Science, 3(17), 24-32. https://doi.org/10.1016/j.sbspro.2011.09.004

Barba-Sanchez, V., \& Atienza-Sahuquillo, C. (2017). Entrepreneurial intention among engineering students: The role of entrepreneurship education. European Research on Management and Business Economics, 24(1), 53-61. https://doi.org/10.1016/j.iedeen.2017.04.001

Benabou, R., \& Tirole, J. (2003). Intrinsic and extrinsic motivation. Review of Economic Studies, 70(3), 489-520. https://doi.org/10.1111/1467-937x.00253

Bilan, Y., Mishchuk, H., \& Pylypchuk, R. (2017). Towards Sustainable Economic Development via Social Entrepreneurship. Journal of Security \& Sustainability Issues, 6(4), 691-702

Bird, B. (1988). Implementing entrepreneurial ideas: The case for intention. The Academy of Management Review, 13(3), 442-453. https://doi.org/10.2307/258091

Carsrud, A., Brannback, M., Elfving, J., \& Brandt, K. (2017). Motivations: The entrepreneurial mind and behavior. Revisiting the Entrepreneurial Mind, International Studies in Entrepreneurship 185-209. https://doi.org/10.1007/978-3-319-45544-0_13

Çera, G., Cepel, M., Zakutna, S., \& Rozsa, Z. (2018). Gender differences in perception of the university education quality as applied to entrepreneurial intention. Journal of International Studies, 11(3), 147-160. https://doi.org/10.14254/2071-8330.2018/11-3/13

Chmielecki, M., \& Sułkowski, Ł. (2016). Metaphors of entrepreneurship among polish students: Preliminary research findings. Entrepreneurial Business and Economics Review, 4(4), 141-151. https://doi.org/10.15678/EBER.2016.040409

Covin, J.G., \& Slevin, D.P. (1989). Strategic management of small firms in hostile and benign environments. Strategic Management Journal, 10(1), 75-87. https://doi.org/10.1002/smj.4250100107

Deci, E.L. (1975). Inequity and intrinsic motivation. In L. Deci (Ed.), Intrinsic motivation (pp. 187-206). Boston, MA: Springer. https://doi.org/10.1007/978-1-4613-4446-9_7

Douglas, E.J. (2013). Reconstructing entrepreneurial intentions to identify predisposition for growth. Journal of Business Venturing, 28(5), 633-651. https://doi.org/10.1016/j.jbusvent.2012.07.005 
Dvorský, J., Petráková, Z., Zapletalíková, E., \& Rozsa, Z. (2019). Entrepreneurial propensity index of university students. The case study from the Czech Republic, Slovakia and Poland. Oeconomia Copernicana 10(1).

European Commission. (2003). Green paper, entrepreneurship in Europe. Retrieved on August 17, 2018 from http://ec.europa.eu/invest-in-research/pdf/download_en/entrepreneurship_europe.pdf

European Commission. (2010). Europe 2020 - a European strategy for smart, sustainable and inclusive growth. Retrieved on August 17, 2018 from https://eur-lex.europa.eu/legal-content/EN/ALL/?uri=celex:52010DC2020

European Commission, Bureau of European Policy Advisors. (2011). Empowering people, driving change: Social innovation in the European Union. Retrieved on August 17, 2018 from http://ec.europa.eu/docsroom/documents/13402/attachments/1/translations/en/renditions/native

European Commission. (2013). Guide to social innovation. Retrieved on August 17, 2018 from https://ec.europa.eu/eip/ageing/library/guide-social-innovation_en

Elfving, J., Brännback, M., \& Carsrud, A. (2009). Toward a contextual model of entrepreneurial intentions. In A. Carsrud \& M. Brännback (Eds.), Understanding the entrepreneurial mind: International studies in entrepreneurship (pp. 23-33). New York, NY: Springer. https://doi.org/10.1007/978-1-4419-0443-0_2

European Parliament, EMPL. (2010). The Lisbon strategy 2000 - 2010: An analysis and evaluation of the methods used and results achieved. Retrieved on August, 17, 2018 from http://www.europarl.europa.eu/RegData/etudes/etudes/join/2010/440285/IPOL-EMPL_ET(2010)440285_EN.pdf

Fici, A. (2015). Recognition and legal forms of social enterprise in Europe: A critical analysis from a comparative law perspective (Euricse Working Papers, 82/15). Retrieved on August 17, 2018 from EURICSE website http://www.euricse.eu/wp-content/uploads/2015/12/WP-82_15_Fici2.pdf

G. Fekete, É., Bereczk, Á., Kádárné, H.Á., Kiss, J., Péter, Zs., Siposné, N.E., \& Szegedi, K. (Eds.). (2017). Alapkutatás a társadalmi vállalkozások működéséröl. Miskolc, Hungary: University of Miskolc.

Gundolf, K., Gast, J., \& Geraudel, M. (2017). Startups' innovation behaviour: An investigation into the role of entrepreneurial motivations. International Journal of Innovation Management, 21(7). https://doi.org/10.1142/S1363919617500542

Haltiwanger, J.C., Jarmin, R.S., \& Miranda, J. (2010). Who creates jobs? Small vs. large vs. young. (NBER Working Paper 16300). Retrieved on August 17, 2018 from https://www.nber.org/papers/w16300

House, R.J., Hanges, P.J., Javidan, M., Dorfman, P.W., \& Gupta, V. (2004). Culture, leadership, and organizations. The GLOBE study of 62 Societies. Thousand Oaks, CA: SAGE Publications. https://doi.org/10.5860/choice.42-4132

Hurst, E., \& Pugsley, B.W. (2011). What do small businesses do?. Brookings Papers on Economic Activity, 43(2), 73-118. https://doi.org/10.1353/eca.2011.0017

Kane, T. (2010). The importance of startups in job creation and job destruction. Retrieved on August 17, 2018 from https://www.kauffman.org/-/media/kauffman_org/research-reports-and-covers/2010/07/firm_formation_importance_of_startups.pdf

Kerlin, J.A. (2006). Social enterprise in the United States and Europe: Understanding and learning from the differences. International Journal of Voluntary and Nonprofit Organizations, 17(246), https://doi.org/10.1007/s11266-006-9016-2

Ketskeméty, L., \& Izsó, L. (2005). Bevezetés az SPSS programrendszerbe. Módszertani útmutató és feladatgyüjtemény statisztikai elemzésekhez. Budapest, Hungary: ELTE Eötvös Kiadó.

Kozubíková, L., Sopkova, G., Krajcik, V., \& Tyll, L. (2017). Entrepreneurial motives as a differentiating factor in innovativeness (Institute of Economic Research Working Papers No. 156/2017). Retrieved on August 17, 2018 from IDEAS website: https://ideas.repec.org/s/pes/wpaper.html 
Kozubíková, L., Dvorský, J., Cepel, M., \& Balcerzak, A. P. (2017). Important characteristics of an entrepreneur in relation to risk taking: Czech Republic case study. Journal of International Studies, 10(3), 220-233. https://doi.org/10.14254/2071-8330.2017/10-3/16

Krpálková-Krelová, K., \& Krpálek, P. (2016). Possibilities for developing business potential in economic education: Examples of implementation in Slovakia and the Czech Republic. Economics \& Sociology, 9(4), 119-133. https://doi.org/10.14254/2071-789x.2016/9-4/7

Krueger, N.F., Reilly, M.D., \& Carsrud, A.L. (2000). Competing models of entrepreneurial intentions. Journal of Business Venturing, 15(5-6), 411-432. https://doi.org/10.1016/s0883-9026(98)00033-0

Kusa, R. (2016). Measuring Entrepreneurial Orientation in the Social Context. Entrepreneurial Business and Economics Review, 4(3), 117-129. https://doi.org/10.15678/eber.2016.040309

Lönnström, A. (2015). The motivational values of social entrepreneurs (Doctoral dissertation). Retrieved on August 17, 2018 from University of Jyväskylä, School of Business and Economics: https://jyx.jyu.fi/bitstream/handle/123456789/46261/URN:NBN:fi:jyu-201506102258.pdf?sequence=1

Lüthje, Ch., \& Franke, N. (2003). The 'making' of an entrepreneur: Testing a model of entrepreneurial intent among engineering students at MIT. R\&D Management, 33(2), 135-147. https://doi.org/10.1111/1467-9310.00288

Maslow, A.H. (1943). A theory of human motivation. Psychological Review, 50(4), 370-396. https://doi.org/10.1037/h0054346

Mugler, J. (1993). Betriebswirtschaftslehre der klein- und mittelbetriebe. Wien, Austria: Springer Verlag.

Nuttin, J. (1984). Motivation, planning, and action. Leuven, Belgium: Leuven University Press and Lawrence Erlbaum Associates.

O'leary, S. (2015). The role of enterprise and entrepreneurship within higher education and effective economic governance across central and eastern Europe. Economics \& Sociology, 8(2), 143-152.

Radulescu, M., Fedajev, A., Sinisi, C.I., Popescu, C., \& lacob, S.E. (2018). Europe 2020 implementation as driver of economic performance and competitiveness. Panel analysis of CEE countries. Sustainability, 10(2), https://doi.org/10.3390/su10020566

Ryan, R.M., \& Deci, E.L. (2000). Self-determination theory and the facilitation of intrinsic motivation, social development, and well-being. American Psychologist, 55(1), 68-78. https://doi.org/10.1037/0003-066x.55.1.68

Schrör, H. (2006). The profile of the successful entrepreneur - Results of the survey 'Factors of Business Success' (Statistics in focus 29/2006). Retrieved on August 17, 2018 from Eurostat website: https://ec.europa.eu/eurostat/data/database

Shapero, A. (1982). Social dimensions of entrepreneurship. In C. Kent, D. Sexton \& K. Vesper (Eds.), The Encyclopedia of Entrepreneurship (pp. 72-90). Englewood Cliffs, NJ, USA: Prentice-Hall.

Sieger, P., Gruber, M., Fauchart, E., \& Zellweger, T. (2016). Measuring the social identity of entrepreneurs: Scale development and international validation. Journal of Business Venturing, 31(5), 542-572. https://doi.org/10.1016/j.jbusvent.2016.07.001

Soviana, S. (2015). Cooperative, social enterprise, and community-based enterprise: Competing, substituting, or complementing?. Management and Organizational Studies, 2(2), 1-14. https://doi.org/10.5430/mos.v2n2p1

Stanickova, M. (2017). Can the implementation of the Europe 2020 Strategy goals be efficient? The challenge for achieving social equality in the European Union. Equilibrium. Quarterly Journal of Economics and Economic Policy, 12(3), 383-398. https://doi.org/10.24136/eq.v12i3.20.

Turker, D., \& Vural, C.A. (2017). Embedding social innovation process into the institutional context: Voids or supports. Technological Forecasting and Social Change, 119, 98-113. https://doi.org/10.1016/j.techfore.2017.03.019 
UnLtd. (2014). Pushing boundaries: Why some social entrepreneurs are using a for-profit legal form for their ventures, and how they are embedding their social mission. Retrieved on August 17, 2018 from https://unltd.org.uk/uploads/general_uploads/Findings_paper_7_Pushing_Boundaries.pdf

Wach, K., \& Wojciechowski, L. (2016). Entrepreneurial Intentions of Students in Poland in the View of Ajzen's Theory of Planned Behaviour. Entrepreneurial Business and Economics Review, 4(1), 83-94. https://doi.org/10.15678/EBER.2016.040106

World Economic Forum. (2013). Breaking the binary: Policy guide to scaling social innovation. Retrieved on August 17, 2018 from Schwab Foundation for Social Entrepreneurship: http://www3.weforum.org/docs/WEF_Breaking_Binary_Policy_Guide_Scaling_Social_Innovation_2013_2604.pdf

Zygmunt, J. (2018). Entrepreneurial activity drivers in the transition economies. Evidence from the Visegrad countries. Equilibrium. Quarterly Journal of Economics and Economic Policy, 13(1), 89-103. https://doi.org/10.24136/eq.2018.005 


\section{Authors}

The contribution of co-authors is equal and can be expressed as $33 \%$ each of the authors: Z. Bartha prepared the introduction, part of the literature review, and the conclusion part, Andrea $S$. Gubik prepared the statistical calculation, while A. Bereczk did the literature research, and the part about social innovation/entrepreneurship.

\section{Zoltán Bartha}

Associate Professor at the Institute of Economic Theory and Methodology, Faculty of Economics, University of Miskolc, Hungary. PhD in Management and Business Administration. Research focus: institutional economics.

Correspondence to: Zoltan Bartha; Institute of Economic Theory, University of Miskolc; 3515 Miskolc-Egyetemvaros, Hungary. E-mail: zolib@hu.inter.net

ORCID 자 https://orcid.org/0000-0002-9208-7881

\section{Andrea S. Gubik}

Associate Professor of the Institute of Economic Theory and Methodology at the Faculty of Economics of the University of Miskolc (Hungary). PhD in Management and Business Administration, International Comparative Studies.

Correspondence to: Dr. Andrea S. Gubik; University of Miskolc, Faculty of Economics, Institute of Economic Theory and Methodology; 3515 Miskolc-Egyetemváros, Hungary; e-mail: getgubik@uni-miskolc.hu

ORCID (ㄱ) https://orcid.org/0000-0002-7632-9828

\section{Adam Bereczk}

Assistant Lecturer at the Institute of Business Sciences, at the Faculty of Economics of the University of Miskolc (Hungary).

Correspondence to: Adam Bereczk; University of Miskolc, Faculty of Economics, Institute of Business Sciences; 3515 Miskolc-Egyetemváros, Hungary; e-mail: bereczk.adam@uni-miskolc.hu ORCID (1) https://orcid.org/0000-0002-3673-2233

\section{Acknowledgements and Financial Disclosure}

The described study was carried out as part of the EFOP-3.6.1-16-00011 "Younger and Renewing University - Innovative Knowledge City - institutional development of the University of Miskolc aiming at intelligent specialisation" project implemented in the framework of the Szechenyi 2020 program. The realization of this project is supported by the European Union, co-financed by the European Social Fund.

\section{Copyright and License}

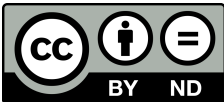

This article is published under the terms of the Creative Commons Attribution - NoDerivs (CC BY-ND 4.0) License http://creativecommons.org/licenses/by-nd/4.0/ 
